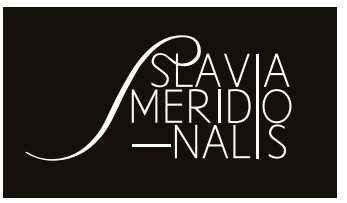

\title{
Jarosław Rubacha
}

Uniwersytet Warmińsko-Mazurski w Olsztynie

\section{Wspomnienie pośmiertne prof. zw. dr hab. Mieczysław Tanty \\ ( ${ }^{\star}$ 19. lipca $1928-\uparrow 22$. kwietnia 2015)}

\author{
Nie umiera ten, \\ kto trwa w sercach i pamięci naszej.
}

Dnia 22 kwietnia odszedł od nas człowiek wielkiej uczciwości i wrażliwości serca, kochający swych bliskich, szanujący przyjaciół, współpracowników i uczniów. Wybitna postać polskiej humanistyki, zasłużony historyk, wychowawca wielu pokoleń bałkanistów. Śmierć bliskiej osoby to bardzo smutne wydarzenie dla rodziny i ludzi związanych ze zmarłym i jakkolwiekmamy świadomość, że jest ona nieunikniona, kiedy nadchodzi, wywołuje ból i głęboki smutek. Profesor Mieczysław Tanty żył między nami, z nami, ale nigdy obok nas. Wszystko, co robił dla rodziny, społeczności akademickiej i swoich uczniów, płynęło wprost z serca, bez oczekiwania na pochwały, honory czy nagrody.

Profesor Mieczysław Tanty urodził się w Dobrzecu (obecnie Kalisz) w 1926 roku, w rodzinie Wawrzyńca i Ewy. Po zdaniu matury w Liceum

This work was supported by the Polish Ministry of Science and Higher Education.

Competing interests: no competing interests have been declared.

Publisher: Institute of Slavic Studies, PAS.

This is an Open Access article distributed under the terms of the Creative Commons Attribution 3.0 PL License (creativecommons.org/licenses/by/3.0/pl/), which permits redistribution, commercial and non-commercial, provided that the article is properly cited. (c) The Author(s) 2016. 
Handlowym Zgromadzenia Kupców w Kaliszu, w 1949 roku, rozpoczął studia historyczne na Uniwersytecie Łódzkim. Po dwóch latach przeniósł się jednak do Warszawy i na wiele lat związał się z Uniwersytetem Warszawskim.

Po ukończeniu studiów w 1955 roku został zatrudniony w Instytucie Historycznym warszawskiej uczelni na stanowisku starszego asystenta. Jednocześnie pod kierownictwem prof. Ludwika Bazylowa rozpoczął prace nad doktoratem, których efektem była dysertacja zatytułowana Zjazd słowiański $w$ Moskwie $w$ roku 1867, obroniona w 1962 roku. Jeszcze w tym samym roku został powołany na stanowisko adiunkta w macierzystym Instytucie. W 1969 roku uzyskał stopień doktora habilitowanego na podstawie pracy Rosja wobec wojen bałkańskich 1912-1913 roku, a następnie został awansowany na stanowisko docenta. W tym czasie rozpoczął szeroko zakrojoną i trwającą z górą dwadzieścia lat działalność organizacyjną. W latach 1971-1975 pełnił funkcję wicedyrektora Instytutu Historycznego Uniwersytetu Warszawskiego, od 1977 do 1981 roku - prodziekana Wydziału Historycznego Uniwersytetu Warszawskiego, a następnie kierownika Studium Podyplomowego Historii Uniwersytetu Warszawskiego (1982-1984) i kierownika Zakładu Historii Europy Wschodniej Uniwersytetu Warszawskiego (1985-1994). W międzyczasie, w 1979 roku, powołany został na stanowisko profesora nadzwyczajnego w Uniwersytecie Warszawskim, a w latach 1979-1980 pracowal jako visiting professor w University of Kansas w Stanach Zjednoczonych. W 1988 roku uzyskał tytuł profesora zwyczajnego.

Równocześnie Profesor Mieczysław Tanty prowadził ożywioną działalność naukową i popularyzatorską. Poszerzając wybrany już w okresie studiów obszar zainteresowań badawczych, obejmujący historię Europy Środkowej i Wschodniej oraz dzieje słowiańskich państw Półwyspu Bałkańskiego, bardzo szybko zajął poczesne miejsce wśród wąskiego grona specjalistów zajmujących się tą tematyką. Wynikiem badań prowadzonych przez niego między innymi w trakcie odbywanych poza granicami staży w Rosji, Bułgarii, Jugosławii i Finlandii były liczne publikacje naukowe, obejmujące dziesiątki książek, redakcji naukowych, recenzji i artykułów naukowych, zamieszczanych w polskich i zagranicznych periodykach naukowych. Wśród nich na szczególną uwagę zasługują zwłaszcza te, w których przybliżał polskiemu czytelnikowi przeszłość bliskiego geograficznie, ale niemal zupełnie nieznanego regionu bałkańskiego. Już w 1968 roku ukazała się jego książka zatytułowana Konflikty bałkańskie w latach 1878-1918, stanowiąca udaną próbę systematyzacji przedwojennych dociekań profesora Henryka Batowskiego 
i prezentująca najbardziej burzliwy okres w dziejach Europy Południowo-Wschodniej, dwa lata później - praca Rosja wobec wojen bałkańskich 1912-1913, w 1982 roku - książka Bosfor i Dardanele w polityce mocarstw, a w 2003 roku popularnonaukowa publikacja Bałkany w XX wieku. Dzieje polityczne, będąca kompendium wiedzy o przeszłości tej newralgicznej części Starego Kontynentu w ciągu minionego stulecia. Nie ulega jednak wątpliwości, że w twórczości Profesora miejsce szczególne zajmują monumentalne prace poświęcone dziejom Słowian południowych i zachodnich, napisane wraz z dwoma innymi specjalistami - Jerzym Skowronkiem i Tadeuszem Wasilewskim - Historia Słowian południowych i zachodnich (1977 i 1988) oraz Słowianie południowi i zachodni VI-XX w. (2005), w których zaprezentowano losy Słowian południowych: Bułgarów, Chorwatów, Czarnogórców, Macedończyków, Serbów i Słoweńców, oraz zachodnich: Czechów, Serbołużyczan i Słowaków, na przestrzeni półtora tysiąca lat, od ich pojawienia się na arenie dziejowej aż po XX wiek. Należy także podkreślić, że publikacje te nie tylko znalazły liczne grono czytelników, ale spotkały się także z uznaniem władz państwowych, które trzykrotnie wyróżniły autora nagrodą Ministra Nauki i Szkolnictwa Wyższego - w 1971 roku za dysertację habilitacyjną, w 1978 roku za książkę Historia Słowian południowych i zachodnich i w 1985 za pracę Bosfor i Dardanele w polityce mocarstw i nagrodziły jego wkład w rozwój polskiej nauki wysokimi odznaczeniami państwowymi i resortowymi, w tym: Krzyżem Kawalerskim Orderu Odrodzenia Polski, Złotym Krzyżem Zasługi i Medalem Komisji Edukacji Narodowej.

Wyrazem uznania dla Profesora były także liczne powołania do różnych komitetów i komisji naukowych, których w jego karierze naliczyć można kilkanaście. Na przestrzeni ponad dwudziestu lat był on między innymi członkiem Komitetu Słowianoznawstwa Polskiej Akademii Nauk, Komitetu Nauk Historycznych Polskiej Akademii Nauk, Komisji Historycznej Polsko-Rosyjskiej Polskiej Akademii Nauk i Rosyjskiej Akademii Nauk, Zarządu Głównego Polskiego Towarzystwa Rusycystycznego, Prezydium Zarządu Głównego Polskiego Towarzystwa Historycznego. Jednocześnie pełnił funkcje wiceprzewodniczącego Komitetu Głównego Olimpiady Historycznej, przewodniczącego strony polskiej i współprzewodniczącego Komisji Polsko-Rosyjskiej do spraw podręczników historii i geografii oraz zasiadał w radach i kolegiach naukowych tak ważnych periodyków naukowych jak: „Studia z dziejów Rosji i Europy Środkowej”, „Dzieje Najnowsze”, „Pamiętnik Słowiański” i „Wiadomości Historyczne". 
Nie sposób nie wspomnieć o pracy dydaktycznej Profesora. W trakcie pięćdziesięcioletniej działalności na tym polu na Uniwersytecie Warszawskim prowadził dla studentów historii i slawistyki wykłady i seminaria $\mathrm{z}$ historii Europy Wschodniej i Środkowej XIX i XX wieku, w trakcie których poczesne miejsce zajmowały kwestie bałkańskie, a wychowując kolejne pokolenia bałkanistów, pozostawił w pamięci swych studentów niepowtarzalne, barwne wspomnienia. Emanował nie tylko erudycją i wysoką kulturą osobistą, ale także wyrozumiałością i dobrodusznością, co zjednywało mu zarówno poważanie, jak i powszechną sympatię. W swojej karierze wypromował setki magistrów i dwóch doktorów (Antoni Giza - 1978 i Piotr Żurek - 2003), był recenzentem dziesiątek prac doktorskich oraz autorem recenzji rozpraw habilitacyjnych i recenzji w postępowaniach o nadanie tytułów profesorskich, a jak trudno było mu się rozstać ze społecznością studencką, może świadczyć fakt, że po przejściu na emeryturę w Uniwersytecie Warszawskim, do 2013 roku kontynuował pracę dydaktyczną w Wyższej Szkole Gospodarki Krajowej w Kutnie.

W skupieniu i zadumie, z żalem w sercach żegnamy śp. Profesora Mieczysława Tantego. Wielki Człowiek, który przez całe życie służył swoją wiedzą innym odszedł od nas, cicho, skromnie, wpół słowa, w pół gestu. Współcześni, którzy czerpali wiedzę z jego dorobku, zachowają o nim pamięć przez całe życie. Jego spuścizna, to wielkie dzieło o nieprzemijającej wartości, przekaże pomięć o Jego trudzie przyszłym pokoleniom, które korzystać będą z ogromu pracy włożonej przez niego w rozwój polskiej bałkanistyki.

Cześć jego pamięci!

\section{Wspomnienie pośmiertne - prof. zw. dr hab. Mieczysław Tanty ( 19 lipca $1928-\dagger 22$ kwietnia 2015)}

Tekst wspomnienia przedstawia drogę naukową i dorobek wybitnego polskiego historyka i znawcy dziejów Słowiańszczyzny, prof. Mieczysława Tantego.

Słowa kluczowe: Mieczysław Tanty, wspomnienie, historia, slawistyka 


\section{Obituary - Professor Mieczysław Tanty $\left({ }^{\star} 19\right.$ July $1928-\uparrow 22$ April 2015)}

This obituary outlines the professional career and work of the outstanding Polish historian and Slavic studies scholar, Professor Mieczysław Tanty (19.07.1928-22.04.2015).

Keywords: Mieczysław Tanty, obituary, history, Slavic studies

\section{Notka o autorze}

Jarosław Rubacha (j.rubacha@wp.pl) - historyk, bałkanista, doktor habilitowany, profesor nadzwyczajny Uniwersytetu Warmińsko-Mazurskiego w Olsztynie. Zainteresowania naukowe: historia Półwyspu Bałkańskiego w XIX i XX wieku, historia Bułgarii; polskie słowianofilstwo na początku XX wieku.

Jarosław Rubacha, PhD (j.rubacha@wp.pl) - Balkanologist, historian, Associate Professor at the University of Warmia and Mazury in Olsztyn. Research interests: history of the Balkan Peninsula in the nineteenth and twentieth centuries; history of Bulgaria; Polish Slavophilism in the early twentieth century. 